\title{
DESTINY AND EVOLUTION OF TV
}

\section{Chair: Fernando Bittencourt - International Director - SET}

Consumers, especially young people, are watching TV less and less open TV. Why is this happening? How to reverse this situation? What new technologies could help? These questions run the world. In this panel/debate, experts from three continents will help us reflect on how to face the challenges that the new digital world brings to the traditional Broadcasting industry.

- Speaker: Lisa Hobbs - Commercial Portfolio Strategy - Compression Solution Area Media - Ericsson

- Speaker: Skip Pizzi - Vice President, Technology Education and Outreach (NAB)

- Speaker: Masayuki Sugawara - President DiBEG ( Digital Broadcasting Expert Group)

- Speaker: Simon Fell - Director of Technology \& Innovation - EBU

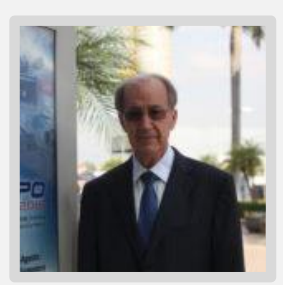

Fernando Bittencourt - International Director - SET

International Director - SET/ Consultant at FB Consultants Former General Manager for Engineering at TV Globo. Graduated in Electronic Engineering from the Federal University of Rio de Janeiro (UFRJ) Beginning in 1994, he was Coordinator of the SET/ABERT group created by the ABERT and SET to study and plan the implementation of Digital TV in Brazil. He was a full member of the Council for Social Communication in the Brazilian Senate, as an engineer with renowned knowledge in the field of social communication. Participates in the Deliberative Council of the Forum on the Brazilian Digital TV System. He is also a member of the IEEE, IBC and the SMPTE. 

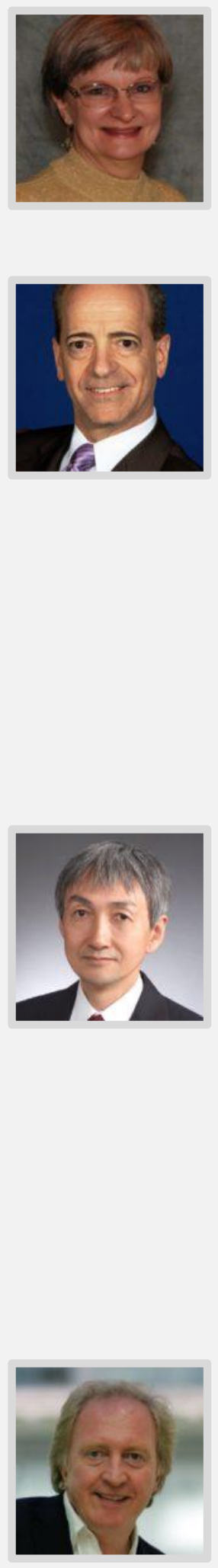

\section{Simon Fell - Director of Technology \& Innovation - EBU}

Simon Fell leads the team spearheading developments in media technologies at the EBU. He has four decades of experience, formerly with ITV as Director of Future Technologies; previously he helped establish Carlton Television where he held several executive positions and helped launch digital broadcasting. He has chaired the Technical Council at the UK's Digital Television Group, and was Chairman of the HD Forum. Additional roles include Director of Engineering for Rushes, Chief Engineer of 625 and establishing Channel Four. His early career included periods in the USA with Rank Cintel and at YTV in Leeds.

Cite this article:

Bittencourt, F., Hobbs, L., Pizzi, S., Sugawara, M. and Fell, S.; 2017. Destiny and Evolution of TV. SET EXPO PROCEEDINGS. ISSN Print: $2447-0481$. ISSN Online: 2447-049X. v.3. doi: 10.18580/setep.2017.4. Web Link: http://dx.doi.org/10.18580/setep.2017.4 